\title{
CRUX MIHI FOEDERIS ARCUS W 40. rocznicę śmierci kardynała Adana Stefana Sapiehy
}

Był ciepły, słoneczny poranek 23 lipca 1951 roku, kiedy niespodziewanie potężny głos dzwonu „Zygmunta” dał się słyszeć w podwawelskim grodzie. Wieść niosła się w nim żałobna: oto odszedł do Pana arcypasterz krakowski, książę krwi i książę Kościoła - Adam Stefan Sapieha. Tradycyjnym zwyczajem trumna ze śmiertelnymi szczątkami biskupa krakowskiego została umieszczona na katafalku w bazylice oo. Franciszkanów, by wierni mogli oddać ostatni hołd umiłowanemu Pasterzowi. W czwartek 26 lipca po południu, w miarę jak zbliżała się pora przeniesienia trumny do krypty w podziemiach królewskiej katedry na Wawelu, widziało się, jakby wszyscy mieszkańcy Krakowa szli tylko w jednym kierunku: ku Rynkowi i ulicy Grodzkiej, którędy miał przechodzić kondukt żałobny.

Pogrzeb Kardynała Sapiehy stał się manifestacją religijną i narodową na skalę, jakiej panująca w Polsce władza komunistyczna ani się spodziewała, ani zdołała zapobiec. Nad trumną krakowskiego Metropolity wstrząsające kazanie wygłosił prymas Polski kard. Stefan Wyszyński. Myślę, że motto wybrane do tego kazania nie mogło być trafniejsze. Kaznodzieja przytoczył na wstępie słowa proroka Jeremiasza, u którego czytamy: I będq walczyć przeciwko tobie, a nie przemoga, bom ja z toba jest, mówi Pan, abym cię wybawit (Jer 1,19). W tych słowach zawiera się zaiste ideowy obraz ziemskiego żywota Adama Stefana Sapiehy.

W jakimż osobliwym kontraście pozostaje ten opis dostojeństwa Kardynała Sapiehy w stosunku do jego fizycznej sylwetki: niewysoki, szczupły, lekko pochylony do przodu, na pierwszy rzut oka sprawiał wrażenie człowieka miernej kondycji, gdyby nie te wspaniałe, arystokratyczne rysy twarzy i czarne, jarzące się oczy. Sam kiedyś, jako chłopiec (było to podczas bierzmowania w roku 1947), doświadczyłem przenikliwości tego spojrzenia o przedziwnej mocy i powadze, zmieszanej z niewysłowioną dobrocią.

Dzisiaj, z perspektywy tylu dziesięcioleci, stawiamy sobie ciągle zasadnicze pytanie: Kimże był ten pasterz z owczarni Pańskiej, że w ciągu 40 lat sprawo- 
wania rządów biskupich na stolicy św. Stanisława pozyskał szczerą miłość i ogromny szacunek ze strony wiernych, ale też sprawił, iż przeciwnicy — swoi i obcy — zniewoleni niezłomnością jego charakteru, odnosili się do niego z najwyższym respektem? Spróbujmy odpowiedzieć na to pytanie, zdając sobie sprawę, że ta odpowiedź pozostanie zawsze niepełna ${ }^{1}$.

Pochodził z kodeńskiej linii Sạpiehów, magnackiego rodu wywodzącego się z Litwy, ale co najmniej od XV wieku odgrywającego ważną rolę polityczną w Rzeczypospolitej Obojga Narodów. Był najmłodszym z siedmiorga dzieci księżnej Jadwigi z Sanguszków i Adama Stanisława Sapiehów. Urodził się 14 maja 1867 r. w krasiczyńskiej posiadłości dziadka Leona, który tu właśnie przed 30 laty osiadł, pozbawiony majątku przez władze rosyjskie za udział w powstaniu listopadowym (1831). Osobowość Adama Stefana kształtowała się w rodzinnym domu między zdecydowanym w działaniu, silnym charakterem ojca a subtelną w uczuciach i głęboko religijną matką. Wszystkich zaś cechowało głęboko zakorzenione poczucie świadomości narodowej, przepojone gorącym patriotyzmem i społecznym zaangażowaniem w służbie narodu.

Jak wiadomo, Adama Stanisława Sapiehę (1828 - 1903) zwano powszechnie ,czerwonym księciem”, co wszakże w odniesieniu do jego osoby nie miało oznaczać jakiegoś radykalizmu społecznego czy ideologicznego, charakteryzującego tak bardzo ówczesną epokę, a tylko jakby paradoksalnie podkreślić, że potomkowie wielkich rodów magnackich nadal powinni przewodzić narodowi polskiemu, nawet jeśli to w warunkach niewoli mogło z nich uczynić spiskowców lub rewolucjonistów i narazić na represje ze strony zaborców. Doświadczył tego na sobie właśnie książę Adam Stanisław Sapieha. Za pomoc kierowaną ze Lwowa do Polaków walczących w powstaniu styczniowym (1863) dostal się do więzienia austriackiego. Przykre to doświadczenie nie zniechęciło go bynajmniej w latach następnych do knucia czasem karkołomnych planów politycznych przeciwko austriackiemu okupantowi mimo pozornej lojalności.

Edukacja szkolna jego najmłodszego syna, Adama Stefana, przebiegała zgoła zwyczajnie. Początkowe nauki otrzymał w Krasiczynie od domowych nauczycieli, ale gimnazjum ukończył we Lwowie; maturę zdał 8 lipca 1886 roku. $\mathrm{Z}$ tego ostatniego okresu zachowała się znamienna pamiątka w zbiorach Biblioteki Jagiellońskiej w Krakowie. Jest nią książka: Deutsche Literaturgeschichte Roberta Koeniga, podarowana w roku 1884 młodemu Sapieże przez jego profesora gimnazjalnego Stanisława Librewskiego i opatrzona wymowną dedykacją: Kochanemu Adasiowi, dla lepszego poznania wrogów naszych wielkości. Potem przyszły prawnicze studia uniwersyteckie w Krakowie i Wie-

${ }^{1}$ Znacznie pełniejsze rozwinięcie postawionej kwestii znajduje się $\mathrm{w}$ artykułach, zamieszczonych w Księdze sapieżyńskiej, t. 1 -2, pod redakcją ks. J. Wolnego (Kraków 1982 - 1986), stanowiącej glówną, choć nie jedyną podstawę niniejszego opracowania. $Z$ tejże publikacji zachowuję skrót: TS (Teka sapieżyńska), odnoszący się do spuścizny archiwalnej po kard. Sapieże, przechowywanej w Archiwum Kurii Metropolitalnej w Krakowie. 
dniu. Ukończył je w latach 1886 - 1890 i dopiero wtedy zrodził się zamiar wstąpienia do stanu duchownego, aczkolwiek już wcześniej pojawił się ten wątek w krasiczyńskim gronie rodzinnym podczas rozmów o przyszłej drodze życiowej najmłodszego z Sapiehów. Decyzja młodego Adama Stefana zapadła ostatecznie (według relacji jego siostry Matyldy Osterwiny) w lecie 1890 roku, gdy przebywał on w Institut Catholique w Lille. Początkowo nosił się z zamiarem wstąpienia do benedyktynów w Beuron, lecz zarzucił tę myśl, gdyż warunkowała ona konieczność opuszczenia Polski. Jesienią 1890 roku zapisał się na teologię w jezuickim uniwersytecie w Innsbrucku. Ukończył ją już jako kapłan archidiecezji lwowskiej (święcenia otrzymal 1 października 1893 roku we Lwowie). Zgodnie z kanonicznym wymogiem spędził następny rok jako wikary w parafii jazłowieckiej koło Buczacza. Już wtedy dał się poznać miejscowej ludności jako ofiarny kapłan, zwłaszcza podczas epidemii cholery, kiedy bez lęku o własne zdrowie posługiwał chorym. Ta wrażliwość na ludzką niedolę stała się busolą działalności pasterskiej Adama Stefana Sapiehy do dni jego ostatnich.

Z Jazłowca książę-wikary wyjechał na dalsze studia za granicę. W roku 1896 uzyskał doktorat prawa na Papieskim Uniwersytecie Lateraneńskim, dopełniony studiami w zakresie służby dyplomatycznej w elitarnej Accademia dei Nobili Ecclesiastici. Swój dwuletni pobyt w Rzymie nie ograniczył młody ksiądz Sapieha do spraw związanych z własną formacją intelektualną. Nawiązane przyjaźnie i znajomości pozwoliły mu już wtedy podjąć pierwsze własne działania kościelno-dyplomatyczne. Merytorycznie dotyczyły one spraw poruszanych w oficjalnych rozmowach, prowadzonych przez Watykan z rządem rosyjskim. Wówczas i w ciągu następnych lat żywo interesował się Sapieha losem Kościoła katolickiego w imperium rosyjskim, zwłaszcza kwestią opieki duszpasterskiej nad zesłańcami polskimi na Syberii, obsadą wakujących biskupstw, stanem Kościoła unickiego, a także wszelkimi próbami rusyfikacji Polaków, podejmowanymi przez władze carskie, czego nie dostrzegali czasem urzędnicy watykańscy i nie doceniali tẻj groźby. Wprawdzie w roku 1897 Sapieha opuścił Wieczne Miasto, wezwany przez abpa Seweryna Morawskiego do pełnienia kolejnych funkcji kościelnych w archidiecezji lwowskiej (1897 - 1906), to jednak — jak się później okazało — nie zapomniał o roli, jaką odegrał w sprawach polskich podczas pierwszego pobytu w Rzymie.

Punktem zwrotnym w kościelnej karierze Adama Stefana Sapiehy było nieoczekiwane powołanie go w roku 1906 do Watykanu na stanowisko cameriere segreto partecipante della Sua Santità. Nie ma całkowitej pewności co do tego, kto zarekomendował księdza prałata Sapiehę do tej służby w Watykanie. Teza postawiona w tej kwestii przez ks. Jerzego Wolnego ma wszelkie znamiona rzeczywistego przebiegu zdarzeń, które do tego doprowadziły, przeto warto ją tu w skrócie przypomnieć ${ }^{2}$.

${ }^{2}$ Zob. J. W ol ny, Adam Stefan Sapieha w Watykanie w latach 1906-1911, [w:] Księga sapieżyńska, t. 1, Kraków 1982, s. $55 \mathrm{nn}$. 
Rok 1905 zaznaczył się na ziemiach polskich zaboru rosyjskiego wzrostem nastrojów patriotycznych i społecznego radykalizmu. W tych to okolicznościach papież Pius X skierowal do arcybiskupa warszawskiego i pozostałych biskupów polskich w zaborze rosyjskim list zaczynający się od słów: Poloniae populum (3 XII 1905). Ojciec Święty wzywał w nim do zachowania pokoju i ładu społecznego, poszanowania władzy, obrony religii i wartości chrześcijańskich, przy okazji wszakże skrytykował wszelkie przejawy radykalizmu. Niestety, słowa papieża wywołały na ogół skutek przeciwny od zamierzonego. W społeczeństwie polskim opinie odnośnie do listu papieskiego uległy polaryzacji —od zachowawczych i solidarnych do antypapieskich, często antykościelnych. W dodatku rząd pruski zaostrzył swą politykę germanizacyjną, przeciwstawiając się w ten sposób przenikającym z Kongresówki nastrojom rewolucyjnym wśród Polaków. Biskupi polscy uznali, że w tej sytuacji należy jak najszybciej wyjaśnić narodowi intencje papieża. W celu uzgodnienia treści takiego komentarza do listu Poloniae populum delegowano do Rzymu arcybiskupa lwowskiego obrządku ormiańskiego Józefa Teodorowicza. Ten po rozmowach z papieżem i sekretarzem stanu kard. Merry del Val taki tekst napisał; opublikowano go z początkiem stycznia 1906 roku na łamach jezuickiego „Przeglądu Powszechnego" w Krakowie. W czasie swego pobytu w Rzymie abp Teodorowicz wysunął ideę utworzenia czegoś w rodzaju biura informacyjnego do spraw polskich przy Watykanie. Ponieważ jednak oficjalne ustanowienie takiej instytucji spotkałoby się na pewno ze zdecydowanym sprzeciwem Rosji, Prus i Austrii, wszystko wskazuje na to, że abp Teodorowicz zasugerował papieżowi myśl powołania polskiego księdza do najbliższego otoczenia papieża, gdzie prócz urzędowych obowiązków - pełniłby także rolę doradcy i informatora w zakresie spraw polskich. Teodorowicz wskazal przy tym na historyczny precedens, i to nie tak dawny, a dotyczący kard. Włodzimierza Czackiego, osobistego sekretarza papieża Piusa IX. Pod ręką zaś miał odpowiednią kandydaturę 39-letniego prałata Adama Stefana Sapiehy, dobrze do tej misji przygotowanego pod każdym względem. Na wiosnę 1906 roku kanonik lwowskiej kapituły metropolitalnej ks. Adam Stefan Sapieha przejął swoje obowiązki przy boku papieża Piusa X.

Nie sposób w kilku zdaniach nakreślić wielości i zakresu zadań, jakich odtąd podejmował się monsignor Sapieha. Warto może w tym miejscu przypomnieć sprawę szczególnie żywo poruszającą wówczas Polaków, jednocześnie mającą swoje reperkusje w Watykanie. Chodziło o metody germanizacyjne, stosowane w zaborze pruskim przez władze niemieckie wobec ludności polskiej. Jak wiadomo Polacy odpowiedzieli strajkiem szkolnym. Na lekcjach religii, prowadzonych w języku niemieckim, dzieci polskie nie odpowiadały na pytania nauczycieli, nie przyjmowały katechizmów niemieckich. Władze pruskie zareagowały represjami, nakładając na rodziców grzywny pieniężne lub kary więzienia, dzieci poddawano publicznej chłoście. Sapieha włączył się w tę 
bolesną sprawę świadomy, że walka o język narodowy ma podstawowe znaczenie w zmaganiach Polaków $\mathrm{z}$ różnorodnością metod germanizacyjnych, jawnych i maskowanych przez zaborców. Gromadził więc materiały źródłowe, by uświadomić Stolicy Apostolskiej, jakimi sposobami rząd pruski prowadzi germanizację i protestantyzację katolickiej ludności polskiej. Dzięki Sapieże kuria rzymska miała wystarczające informacje o walce narodowej i religijnej Polaków w zaborze pruskim. Naturalnie politycy pruscy usiłowali przekonać swoich rozmówców watykańskich o groźbie rewolucji społecznej; przedstawiano więc Polaków jako buntowników i wichrzycieli porządku publicznego, polską zaś walkę o język narodowy w nauce religii jako ruch ideologiczny, związany $\mathrm{z}$ radykalnymi wydarzeniami w zaborze rosyjskim. Do tego doszła sprawa obsady arcybiskupstwa gnieźnieńskiego po śmierci abpa Floriana Stablewskiego (24 XI 1906), zakończona dopiero w roku 1914, kiedy w obliczu wojny cesarz Wilhelm II uczynił gest wobec ludności polskiej, wyrażając zgodę na objęcie tej prastarej, polskiej stolicy kościelnej i narodowej przez bpa Edwarda Likowskiego. Sprawy polskie w zaborze pruskim nie były oczywiście jedynymi, w jakie angażował się monsignor Sapieha podczas swego pobytu na dworze papieskim. Stan Kościoła i sytuacja Polaków na wschodnich terenach dawnej Rzeczypospolitej pozostawały ciągle w perspektywie jego zainteresowania i serdecznej troski. Można by jednak zapytać o rezultaty blisko sześcioletniej „tajnej misji” Adama Stefana Sapiehy w Watykanie. Na to pytanie odpowiedział on sam w 10 lat po objęciu biskupstwa krakowskiego. Spędzone tam lata wspominał mile, aczkolwiek pozostawiły one też pewną dozę daremnych oczekiwań w zakresie pelnionej przezeń roli w Watykanie. Oto jego słowa:

Z Rzymu przybyłem [do Krakowa w roku 1912] zostawiając tam jak najlepsze relacje, Papieża łaskawie usposobionego i pewien serdeczny stosunek w Watykanie, gdzie wracając dwa razy, spotykałem prawie rodzinne stosunki, niezmiernie miłe. Na kierunek w ważniejszych sprawach nie mogło to mieć wielkiego wpływu, jednak czułem się tam zawsze jak najlepiej przyjęty i widocznie miano zaufanie do mnie, choć nie zawsze robiono to, co przedstawiałem. Byłem w rozmaitych sprawach zapytywany ${ }^{3}$.

Dalszy ciąg cytowanych wspomnień dotyczy już okresu krakowskiego w życiu Adama Stefana Sapiehy jako biskupa na stolicy św. Stanisława. Nie ma pewności co do tego, kto postawił wniosek o powierzenie prałatowi Sapieże steru nawy kościelnej Krakowa po śmierci (8 IX 1911) kard. Jana Puzyny. Wprawdzie minister WRiOP hr. Karol von Stürgkh powoływał się w swoim piśmie do cesarza Franciszka Józefa I na rekomendację abpa Bilczewskiego, lecz wiado-

${ }^{3}$ TS 36 z. 5 s. 69 (zob. wyżej przypis 1). Ten i następne cytaty pochodzą z niezmiernie interesującego i ważnego autografu kard. Sapiehy, napisanego $\mathrm{w}$ roku 1922 . Jest to rodzaj pamiętnika, obejmującego lata 1912 - 1922. Autor spisal swe wspomnienia na 17 stronach zeszytowych (s. 69 -85 paginowane przez ks. Piwowarczyka), nieoprawnych. Teka 36 (właściwie jest to pudło tekturowe) zawiera jeszcze inne rękopisy Sapiehy, głównie dotyczące początkowych lat jego pasterzowania w Krakowie. 
mo, że nad obsadą biskupstwa krakowskiego debatowano wcześniej w różnych kręgach kościelnych i politycznych Galicji, co potwierdza np. ówczesny namiestnik Galicji Michał Bobrzyński w swoich pamiętnikach ${ }^{4}$. Ostatecznie cesarz mianował (6 XI 1911) ,kanonika rzymsko-katolickiej Kapituły metropolitalnej we Lwowie Adama księcia Sapiehę na stanowisko księcia-biskupa w Krakowie". Nominacja ta zostala zaprezentowana na konsystorzu papieskim (27 XI) i tego samego dnia nastąpiła prekonizacja papieska. Pius X osobiście dokonal konsekracji Adama Stefana Sapiehy, co nastąpiło 17 grudnia tegoż roku w Kaplicy Sykstyńskiej. W trzy miesiące później (3 III 1912) nowy biskup krakowski, mało znany w tamtejszym środowisku przedstawiciel powszechnie znanego rodu magnackiego, odbywał wspaniały ingres do katedry królewskiej na Wawelu.

W przekonaniu duchowieństwa krakowskiego czy w ogóle — galicyjskiego, Sapieha obejmował w pasterskie władanie „diecezję idealną”. Tymczasem $\mathrm{z}$ dziesięcioletniej perspektywy sam zainteresowany tak ujął zastany stan rzeczy w powierzonej mu prowincji kościelnej:

Zastałem diecezję w stanie zewnętrznym dobrze zorganizowaną pod twardą ręką kardynała. Długoletnia jego choroba jednak wytworzyła obok niego rządy poboczne, zasłaniające się jego postrachem, bardzo niechętne nowemu przybyszowi, bo <od > chwili konsekracyi, a tem bardziej przyjazdu do Krakowa, chciano mi narzucić dawny system, opierający się głównie o pewne osoby, jak o teoretyczne poglądy, bo te były tylko potrzebne, by osoby miały pewny stan posiadania. Ruszenie którejkolwiek z osób było też uważane za herezję. Przeciwstawiano się nie gwałtownie, ale cichcem [...]. Chodziło o to, by mi wykazać, że nie wolno nic zmieniać. Jak zawsze taki konserwatyzm głównie opiera się na egoizmie i martwotę rodzi, tak w diecezji, jak w Seminarium dostrzegłem zaraz, że system ten zabiłby zupełnie życie i rozwój [...]. System poprzedni miał to do siebie, że niszczył indywidualności, wszystkich pogrążał w pewien sen i bierność, którą pokrywano zwykłymi frazesami ${ }^{5}$.

Twarde to słowa. Jeśli dzisiaj spotyka się opinie historyków, określające Sapiehę jako konserwatystę na różnych płaszczyznach jego działalności kościelnej czy społecznej, to warto przy tym pamiętać również o powyższym jego wyznaniu.

Pragnąc nakreślić choćby pobieżnie dzieje biskupich rządów kardynała Sapiehy, należałoby w znacznej mierze powtórzyć historię Polski pierwszej połowy obecnego stulecia. $Z$ konieczności więc przypomnę ważniejsze wydarzenia, świadczące dobitnie o historycznej roli, jaką w tym okresie Książę-Biskup krakowski odegrał w dziejach Kościoła i narodu polskiego.

Ledwie I wojna światowa zaczęła zbierać swoje krwawe żniwo, bp Sapieha wystosował (25 XII 1914) apel do narodów świata o pomoc dla ofiar wojny w Polsce. Tę płomienną odezwę przedrukowała niemal cała prasa polska,

${ }^{4}$ M. Bobrzyńs ki, Z moich pamiętników, Wrocław-Kraków 1957, s. 349, 371 n.

5 TS 36 z. 5 s. $70-71$. 
a także wiele dzienników europejskich (np. „L'Osservatore Romano”, „Kölnische Volkszeitung”, „Reichspost” i inne) oraz amerykańskich. Nim jednak zaczęły napływać pierwsze dary, bp Sapieha zorganizował komitet ratunkowy, zatwierdzony 19 maja 1915 roku przez austriackie władze Galicji; oficjalnie był to Krakowski Biskupi Komitet Pomocy dla Dotkniętych Klęską Wojny, ale w powszechnym użyciu tę przydługawą nazwę skrócono i nazywano go Książęco-Biskupim Komitetem lub jeszcze krócej - KBK. Wydawać by się mogło, że tak szczytna inicjatywa Biskupa krakowskiego spotkała się od razu ze zrozumiałym, solidarnym poparciem ze strony duchowieństwa i szerokich kręgów katolickiego społeczeństwa. Rzeczywistość wszakże okazała się bolesna dla krakowskiego Pasterza. Po latach wspominał z goryczą: „Założyłem KBK. W klerze i sferach katolickich, mimo szukania, nie znalazłem ofiarnych. Po próbach kilku musiałem udać się do innych ludzi, z dala od Kościoła stojących, którzy okazali się doskonałymi pracownikami i ludźmi bardzo porządnymi"6. Jednym z nich był dr Jan Górski, ,agnostyk, dość wojowniczo do religii nastawiony, a zarazem typowy kulturalny rentier", który po utworzeniu KBK został (po prałacie Marcelim Ślepickim) niezwykle czynnym sekretarzem tegoż Komitetu, „prawą ręką biskupa Sapiehy w jego pracy filantropijnej i społecznej, powiernikiem jego zamiarów i szeroko zakrojonej działalności"7. Zaiste, jakże niezwykłych robotników powołuje Pan Bóg do pracy w winnicy swojej!

Działalność Komitetu objęła całe terytorium polskie. Tam, dokąd nie można było wysłać własnych ludzi i gdzie nie dało się rozwinąć wypracowanych już struktur organizacyjnych, posyłano pieniądze do znanych towarzystw charytatywnych. Tak było np. z Warszawą, dokąd przesłano 250000 koron. Wiele instytucji i zakładów dobroczynnych KBK przetrwało wojnę i już w wolnej Polsce kontynuowało swą działalność, choć formalnie zakończył on statutową egzystencję. Przykładem tego były „szpitale kolumn sanitarnych im. Księcia Biskupa Sapiehy". Stały się one zalążkiem służby zdrowia w odrodzonej Polsce $^{8}$. W czasach „wielkiej wojny” wsławiły się one przede wszystkim ratowaniem dzieci i akcją masowych szczepień przeciwko ospie (objęła ona około dwa miliony ludzi). Ogromną zasługą KBK było zaktywizowanie polskiego społeczeństwa w dziele publicznego miłosierdzia w trudnym okresie tworzenia się państwowości polskiej po przeszło stuletnim okresie niewoli.

Działalność pasterska bpa Sapiehy w okresie I wojny światowej nie ograniczyła się tylko do akcji charytatywnej. Nigdy nie zapomniał on o swym podsta-

${ }^{6}$ TS 36 z. 5 s. 75

${ }^{7}$ Ze wspomnień Krzysztofa Morawskiego o kard. Sapieże; zob. Księga sapieżyńska, t. 2, Kraków 1986, s. 674 n.

8 Pisal o tym po latach bliski współpracownik bpa Sapiehy w KBK prof. Emil Godle ws ki: Dziatalnośc księcia metropolity A. S. Sapiehy w okresie wielkiej wojny, Kraków 1926, s. 16. NajpeIniejszą jednak, jak dotąd, informację o działalności Książęco-Biskupiego Komitetu zawiera książka opracowana przez wspomnianego wyżej Jana Górskiego, pt. Trzy lata dziatalności KBK (1915 -1917), Kraków 1918. 
wowym zadaniu, jakim było sprawowanie kultu Bożego poprzez szafarstwo sakramentów, nauczanie wiary, wszelkiego rodzaju formy duszpasterskie. Warto podkreślić ten aspekt bis k u pi ch obowiązków ordynariusza krakowskiego, wypełnianych przezeń z pełną konsekwencją w warunkach chaosu, powszechnej nędzy, rozprzężenia norm współżycia społecznego w czasie niszczącej kraj i naród totalnej wojny. Książę-biskup krakowski urzeczywistniał w ten właśnie sposób dewizę św. Piusa X: Instaurare omnia in Christo.

W tamtych tragicznych dniach wojennych rozwijała się jeszcze jedna sprawa, w którą bp Sapieha zaangażował cały swój autorytet. Chodziło o przyszłość Polski. W tej kwestii nie istniała dla niego żadna alternatywa, kompromisy czy gra polityczna. Tymczasem zdarzało się, że rozmaite ośrodki władzy lub jakieś kręgi patriotyczne o różnym zabarwieniu ideowym domagały się niekiedy złożenia przezeń jakiejś deklaracji politycznej. W sierpniu 1914 roku powstał w Krakowie Naczelny Komitet Narodowy (NKN), hołdujący ideom socjalistycznym. Sapieha odciął się zdecydowanie od tego ruchu politycznego i reprezentującej go instytucji ${ }^{9}$. Po latach zapisał w cytowanej pamiętnikarskiej relacji:

Zaraz od początku stanąłem przeciwko robocie NKN, jako podstępnej, nieuczciwej, odtąd też rozłam z partią konserwatywną stał się głębszy, otwartszy. Nie mogąc mnie zwalczać otwarcie, szyto buty potajemnie, głównie starano się wzbudzić nieufność władz wojskowych. Dzięki jednak stosunkom z najwyższymi sferami na<ro>dowymi mimo wszystko udało się bez większych nieprzyjemności przejść ten czas nie łatwiejszy jak przyszły ${ }^{10}$.

Aluzja uczyniona w powyższej zapisce na temat „władz wojskowych” mogła dotyczyć legionów, wobec których Ordynariusz krakowski zachował rezerwę. Sądzę jednak, że tę spowodowała raczej „socjalistyczna etykieta” przyklejona do rodowodu legionów, co w owym czasie wiązano przede wszystkim z antykościelną czy wręcz antyreligijną postawą socjalistów europejskich, naturalnie nie do przyjęcia dla osoby odpowiedzialnej za powierzony jej „rząd dusz"11. W stosunku do legionów Józefa Piłsudskiego wypełnił bp Sapieha

${ }^{9} \mathrm{~W}$ tym miejscu należy poprawić dość istotny błąd, na który zwrócil mi uwagę ks. prof. Wolny, a mianowicie występujący w artykule ks. B. Pr z y b y s ze w s k i e g o: Kalendarium działalności spotecznej ks. bp. Adama Stefana Sapiehy podczas I wojny światowej, „Chrześcijanin w Świecie” $14: 1982 \mathrm{nr} 8 / 10$ s. 108. Znajdujemy tam wiadomość, jakoby bp Sapieha poparł w roku 1914 Naczelny Komitet Narodowy i nawet udzielił mu subwencji w wysokości 10000 koron. Chodzi tu o Centralny Komitet Narodowy, niebawem zresztą rozwiązany; zob. M. Ku ki e l, Dzieje Polski porozbiorowej (1795 - 1921), Londyn 1963, s. 579; „Czas” 67 : 1914 (21 VIII 1914) nr 368. Sapieha nigdy nie zmienil swego negatywnego stosunku do NKN-u; zob. H. Le m ke, Allianz und Rivalität. Die Mittelmächte und Polen im ersten Weltkrieg, Berlin 1977, s. 303.

10 TS 36 z. 5 s. 76.

11 Zob. TS 36 z. 22. Jest to z kolei rodzaj dziennika, rejestrującego czynności bpa Sapiehy w dniach 24 IV - 25 V 1917. Na s. 2-4 (nlb.) relacjonuje Sapieha swoją rozmowę, odbytą z cesarzem Franciszkiem Józefem I (13 maja). Znajdujemy tu fragment wypowiedzi Sapiehy, ilustrujący jego stosunek do socjalistów, a jednocześnie dający obraz aktualnej sytuacji politycznej. Mówiąc o anarchii, rozpaczy i łatwemu uleganiu różnym ideologiom przez ludność, Sapieha miał powiedzieć: „Socjaliści rozumieli to dobrze i jak z początku wojny cicho siedzieli, tak teraz na wszystkie 
swój podstawowy obowiązek duszpasterski, zapewniając żołnierzom opiekę kapłańską ze strony kapelanów wojskowych. Ostatnim aktem, zamykającym niejako jego dokonania i nadzieje czasu niewoli, było orędzie wystosowane 1 listopada 1918 przez biskupów galicyjskich (abpa Bilczewskiego i Teodorowicza oraz bpa Sapiehę, Pelczara i Wałęgę) do wiernych, wzywające do uczestniczenia w dziękczynnych nabożeństwach za powstanie wolnej, niepodległej i zjednoczonej Polski i do odśpiewania we wszystkich kościołach Te Deum oraz hymnu Boże coś Polskę.

W Polsce Odrodzonej skupił się Sapieha na pracy duszpasterskiej, charytatywnej i wychowawczej. Zdawał sobie doskonale sprawę z tego, że idą nowe czasy, wymagające odmiennych metod niż te, dotąd stosowane, aby zasady chrześcijańskie mogły wypełnić życie wiernych i całego społeczeństwa polskiego. Rozumiał też, że w skomplikowanych warunkach życia gospodarczego, społecznego i politycznego stoją przed młodym duchowieństwem nowe zadania, które wymagają od kapłanów przygotowania nie tylko w zakresie wiedzy teologicznej, lecz także nauk filozoficznych, społecznych, ekonomicznych. Stąd też brała się troska Sapiehy o Wydział Teologiczny Uniwersytetu Jagiellońskiego, o kształcenie księży na katolickich uniwersytetach Włoch, Francji, Austrii i Belgii. Warto może w tym miejscu przypomnieć, że jednym z ostatnich, który właśnie kard. Sapieże zawdzięczał swoje studia zagraniczne, był ks. Karol Wojtyła.

Najdramatyczniejszą kartę w życiu abpa Sapiehy zapisała okupacja hitlerowska w Polsce. Nie bacząc na osobiste bezpieczeństwo, słał protesty do władz III Rzeszy przeciwko masowym egzekucjom, przeciwko stosowaniu zasady odpowiedzialności zbiorowej, przeciwko wywózce Polaków do pracy niewolniczej w Niemczech, przeciwko barbarzyńskiemu okrucieństwu okupanta. $\mathrm{Z}$ całą mocą interweniował w sprawie uwolnienia 183 profesorów uniwersyteckich z Krakowa, aresztowanych i wywiezionych do obozu koncentracyjnego w Sachsenhausen, Dachau i Mauthausen-Gusen w listopadzie 1939 r. Dopominał się od niemieckiego episkopatu — zresztą daremnie - opieki duszpasterskiej nad Polakami, wywiezionymi do Niemiec. Domagał się uwolnienia polskich księży i biskupów, osadzonych w różnych obozach koncentracyjnych (głównie w Dachau). Te i wiele innych aktów odwagi Arcybiskupa-Metropolity krakowskiego uzmysławiały niemieckiemu okupantowi, że nie oni, ale właśnie ten drobny niepozorny z wyglądu kapłan w zwykłej czarnej sutannie sprawuje faktyczne rządy nad duszami wpatrzonych weń z nadzieją Polaków. Toteż próby pozyskania go do choćby pozornej kolaboracji kończyły się zawsze bezdyskusyjną odmową z jego strony. Jak przed 40 laty, tak też podczas okupacji hi-

strony ruszają się, ukazują się jedynymi przyjacielami ludności i jej opiekunami, gdy my katolicy milczymy”. I dalej: „Przykład rewolucji i radykalizmu rosyjskiego jest niebezpieczny właśnie z powyższego powodu. Gdyby im jeszcze udało się sprowadzić pokój, zawojują całą Europę”. Co za prorocze słowa! 
tlerowskiej stał się znowu głównym informatorem Stolicy Apostolskiej na temat losu Polaków i polskiego Kościoła. Pozostawał w stałej łączności z polskim rządem w Londynie i ruchem oporu w kraju.

Po wojnie, w zmienionych warunkach politycznych kard. Sapieha miał świadomość dokonujących się przemian na różnych płaszczyznach życia społecznego. Widział nieodwracalność procesu, który zmierzał do stopniowej „detronizacji” czynnika europejskiego w Kościele i we współczesnej kulturze. Realistycznie oceniał sytuację polityczną w Polsce, zachowując w tej kwestii przyjętą przez episkopat polski linię postępowania. Poczucie odpowiedzialności za Kościół w Polsce i dobro narodu kazały mu — już po raz ostatni — włączyć się w sprawę jakiegoś uregulowania stosunków między Polską pod rządami ateistycznej władzy a Stolicą Apostolską. Czterokrotnie wyjeżdżał do Rzymu, gdzie prowadził rozmowy $\mathrm{z}$ najwyższymi władzami kościelnymi na temat sytuacji Kościoła w Polsce. A był to czas represji, stosowanych przez władze państwowe wobec tegoż Kościoła, zwłaszcza kierowanych przez niego instytucji społecznych (np. likwidacja „Caritasu” w styczniu 1950), ale też czas intensywnych starań episkopatu Polski do unormowania współżycia Kościoła i państwa. Kiedy w kwietniu 1950 doszło ostatecznie do podpisania znanego porozumienia $\mathrm{z}$ władzami rządowymi, regulującego $\mathrm{w}$ jakimś stopniu wzajemną relację państwa i Kościoła w Polsce Ludowej, kard. Sapieha przebywał w Rzymie. Jego misja polegała - jak się zdaje — na tym, by uzyskać zgodę od władz kościelnych na zawarcie owego porozumienia bez konieczności przeprowadzania odpowiednich rozmów w tej sprawie w Sekretariacie Stanu. Niebezpieczna sytuacja Kościoła w Polsce wymagała szybkiego działania w tej sprawie. Kard. Sapieha wypełnił swoją ostatnią misję, jak tego wymagało dobro Kościoła i dobro jego Ojczyzny.

W dziejach narodu i Kościoła polskiego najmłodszy syn Sapiehów z Krasiczyna, choć fizycznie wątły i miernej postury, okazał się mocą żarliwej wiary i niezłomnością charakteru „wielkim synem swojej Ojczyzny; stanowczym w trudnych momentach, odważnym ponad miarę jakiejkolwiek przeciętności [...], niezwykłym mężem dziejów i Polski" "12. On sam określił wyraźnie źródło siły duchowej, jaką dysponował w stopniu wzbudzającym zdumienie u tych, którzy mieli z nim styczność. Ujął to zwięźle w słowach wypisanych na swym herbie biskupim, a zaczerpniętych z Księgi Rodzaju $(9,13)$ : CRUX MIHI FOEDERIS ARCUS — Krzyż będzie mi znakiem przymierza!

${ }^{12}$ Słowa kard. Karola Wojtyły (7 V 1976); zob. Księga sapieżyńska, t. 2, Kraków 1986, s. 580. 


\section{DAS KREUZ IST MIR DAS ZEICHEN DER VERHEISSUNG \\ Zum 40. Todestag Kardinals Adam Stefan Fürst Sapieha}

\section{Zusammenfassung}

Im Juli 1991 verging der 40. Todestag des Krakauer Erzbischofs Kardinal A. S. Sapieha. Er gehörte zu den bedeutendsten Persönlichkeiten in der Geschichte des polnischen Volkes und der polnischen Kirche in der ersten Hälfte des 20 . Jh. In zwei Zeitperioden machten sich seine ungewöhnlichen Charakterzüge, sein unerschtterlicher Glaube und seine evangelische Barmherzigkeit besonders sichtbar. Das war während der beiden Weltkriege. Die Haltung und die Tätigkeit des Krakauer Seelensorgers wurden damals zu einer Festung für Schwache und den Zweifelnden flössten sie die Hoffnung ein. Er selbst bestimmte deutlich die Quelle seiner geistigen Kraft, indem er auf seinem Bischofswappen die im Titel zitierten Worte schreiben ließ: Crux mihi foederis arcus (Gn 9,13). 